consistentlv by NATURE, that the surest and best way to secure national efficiency is to educate our manufacturers and merchants liberally along scientific lines, and to enlist the cooperation of distinguished men of science in the work of national administration.

In considering the task that lies before a progressive political party, Mr. Haldane has much of interest to the man of science to say about things the party has to accomplish in the process of winning complete public confidence in its capacity to direct national business. He points out that the importance of each Department of State depends mainly on the personality of the Minister who presides over it. But apart from personality there are other forces -such as clear conception and resolute purpose-which profoundly affect administration. To bring into play greater brain power in administration is, Mr. Haldane insists, a task of the first magnitude, and he proceeds to show its importance and how it may be accomplished.

The appointment of the Explosives Committee by Lord Lansdowne in 1900 is the first illustration taken by $\mathrm{Mr}$. Haldane. After the outbreak of the South African war, it came to light that the British military and naval guns were being corroded rapidly by the chemical action at high temperatures of the products of combustion of the nitroglycerin in the cordite. Lord Lansdowne, who summoned outsiders to advise him, was told that an expert committee on the national explosives required the best scientific brains in the country, and, following the earlier example in France, a committee, presided over by Lord Rayleigh and including Sir Andrew Noble and Sir William Crookes, was appointed. The committee has solved the problems presented to it, made further discoveries, and is now a permanent body. But the committee is performing its work under great difficulties, due entirely to our system of administration. As Mr. Haldane says, "the Army gives its rewards to genius on the field, and not to genius in the laboratory." $\mathrm{He}$ says later:- "If the British Government is to have adequate command of scientific talent of the highest order, it must make arrangements which will enable it to reward and honour that talent on an adequate scale, without exciting ill-feeling."

There ought, in fact, Mr. Haldane contends, to be an advisory body with a corps scientifique attached to it, which should include the exceptional talent which the State stands more and more in need of every day. Not only would such a scientific committee provide a new opening for talent, but, more important, prove a source of new strength to the nation. As a further instance of the good results which promptly follow the application of scientific methods to national problems, Mr. Haldane cites the case of the discovery among miners of the disease ankylostomiasis, after the Home Office had obtained the permission of the Treasury to appoint a committee of investigation, and indicates how great would have been the saving of suffering and money had there been a corps scientifique to appeal to as a matter of course.

Referring to the fall in the amount of exports in some branches of industry, Mr. Haldane traces this to the need for more mind in the process of manufacture, that is, for the improvement of higher education in this country, and goes on to remark that comparatively little State aid has been devoted to this important necessity. Exception is taken, too, to the somewhat mechanical methods of distribution of the present grant from the Treasury to university colleges, and it is urged that in this direction also the executive brain ought to be strengthened.

The Centralstelle of Germany, the function of which is to put at the disposal of inquirers, in the solution of problems arising in manufacture, the best scientific knowledge available which cannot otherwise be obtained by the private manufacturer, is an example of Germany's appreciation of men of science. Not only are such central research institutions established in Germany, but also in the United States and in France. The same principle has been conceded among us, for the State gives a small grant -just about a tenth of what the Germans give to their corresponding institution-to the National Physical Laboratory, an invaluable institution which is at present being starved. Well may Mr. Haldane say that "it is time for the State to take the lead in this direction also, if we are to hold our own in the international competition which is more and more coming to depend on the application of science to industry."

The essay as a whole is a powerful plea for the introduction of the methods of science into every department of national life, and should convince every reader that disregard of scientific method and procedure is of necessity accompanied by a want of national efficiency and wellbeing.

\section{CORAL ANATOMY AND DEVELOPMENT.'}

$\mathrm{I}^{\mathrm{N}}$ writing this account of his observations and researches on Siderastræa, Dr. Duerden has added an important contribution to his already extensive publications on the anatomy and development of the Madreporaria. Siderastræa is a common West Indian coral forming colonies of $10 \mathrm{~cm}$. to $60 \mathrm{~cm}$. in diameter, which encrust stones and some times the shells of hermit crabs on the coral flats. It appears to be exceedingly hardy, as it will suffer exposure to the hot sun at low tide and partial burying in the mud without injury, and it is often found living under conditions on the reef which very few corals of other species could withstand. This hardiness renders it an admirable type for thorough investigation, as it enables it to live and grow and reproduce itself freely in the unfavourable conditions of an aquarium in the tropics.

Siderastræa, although a colonial coral having a general superficial resemblance to the Astræidæ, or star corals, is allied to the Fungidæ, or mushroom corals. The tissues of the expanded zooids are so transparent that the white

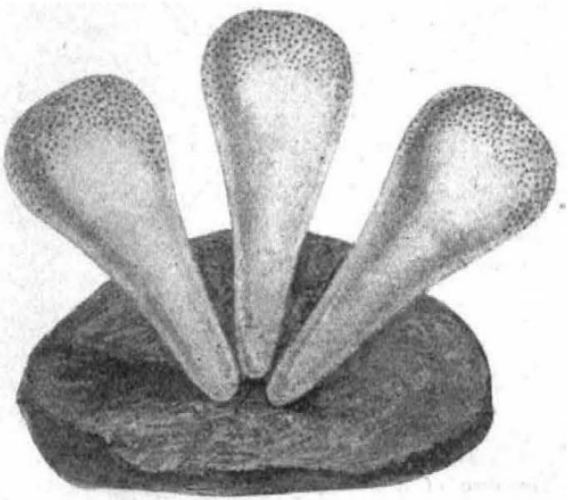

F1G. I.-Three larvæ of Siderastræa settling down upon a stone, in close proximity, by their narrow aboral poles.

skeletal structures can be seen through them. Each zooid has, in the adult state, two rows of capitate tentacles, and several of the members of the inner row are bifurcate. This remarkable and, among corals, unique condition of the tentacle is brought about by the growth of a common peduncle for a pair. of neighbouring tentacles of the entocolic series which are primarily distinct.

In all the zooids that were examined anatomically only ova were found; Dr. Duerden, however, gives reasons for believing that the coral is not strictly diœcious, but protogynous, a point of some interest when compared with the case of Flabellum rubrum, which Mr. Stanley Gardiner has shown to be protandrous.

The early stages of the development of the coral take place within the cavity of the parent zooid, and the ciliated top-shaped larve are discharged with four pairs of mesenteries already developed. The larvæ can be kept alive in the aquaria for several weeks, but unless they settle down within the first two or three days from liberation it seems impossible for them to fix themselves, and they ultimately perish. In general the larvæ fix themselves at the same time and in groups. So close do they cluster together that they are often in touch with one another,

1 "The Coral Siderastraea radians and its Prst-larval Development." By Dr. J. E. Duerder. Pp. r 30 +plates. (Washington: Carnegie Institution, December, 1904.) 
and by mutual pressure produce a distortion of the normally circular base. There can be no doubt that in this coral, as in others investigated by Dr. Duerden, these clusters of larvæ become organically connected, and form aggregated colonies.

In dealing with the later stages of the development, the author discusses many questions of great interest to those who have made a special study of the anatomy of corals. We may refer especially to the light thrown upon the vexed question of "theca" and " epitheca," to the demonstration that the primary ectosepta do not become entosepta as they were supposed to do in some other corals, and to the valuable suggestion as to the scientific method of writing the septal formulæ of corals. These and other matters, which are fully discussed, render the memoir of greater value than a mere record of facts and observations of the natural history of a single species of coral would be. There is a great deal to be said in favour of the old type system, the system of presenting to the reader a plain, unvarnished tale of the natural history of a species and leaving him to draw his own conclusions; but the dangers of the system may be clearly recognised

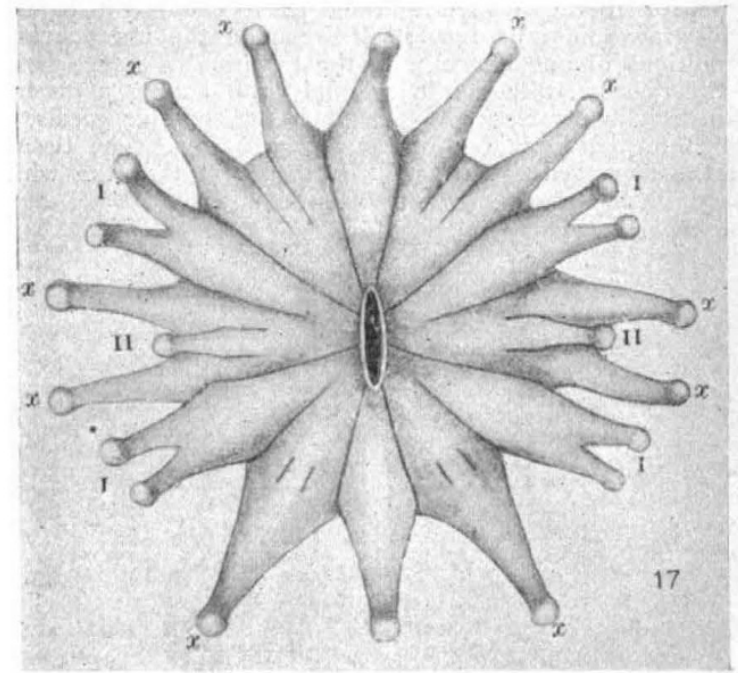

Fig. 2.-The disc of a young Zooid of Siderastræa with expanded tentacles showing (1.1.) the four bifurcate tentacles of the inner row.

in this memoir. The coral under review is a common, and many might think a common-place, coral, and if the author had thought fit to limit himself to a description of facts only, it would probably have been chosen as a type of its order by writers of the conventional text-book. Fortunately, however, we are warned on almost every page that Siderastræa is not a type, but in many respects an exceptional and rather archaic form.

In conclusion, a word of praise must be said for the manner in which the memoir is presented to the public. Like the other scientific treatises that have been recently published by the Carnegie Institution at Washington, the paper, printing, and illustrations are all of first-rate quality.

S. J. H.

\section{GAS CALORIMETRY.}

$\mathrm{IN}$ the recent report of the Departmental Committee appointed to consider the question of the control of the gas supply of the metropolis, a proposal was made that the calorific power of the gas should be regularly determined, thus recognising the growing importance of the heating value of gas as distinguished from its illuminating power. The use of gaseous fuel both for heating and power purposes having led to a demand for exact gas calorimetry, several types of calorimeter have come into use. In those of the Junker type, the gas is burned at a NO. I 860 , VOL. 72$]$ measured rate, and the products of combustion are cooled down by a stream of water also flowing at a known rate, the ingoing and outgoing temperatures of which can be accurately measured. In spite of the difficulties of securing accurate measurements of the rate of flow of gas and water, on account of the speed with which consecutive determinations can be carried out instruments of this type are mostly used by gas engineers. Their chief defect is want of portability, and as an alternative a sample of the gas is frequently analysed, and the calorific value deduced from the results of the analysis. Apart from the difficulty of exactly determining the constituents of such a complicated mixture as coal gas, this method implies that the exact calorific value of each substance present is accurately known, and this, unfortunately, is far from being the case.

Most of the data regarding heats of combustion in actual use are derived either from the experiments of Berthelot and his pupils with the calorimetric bomb, or from the experiments of Julius Thomsen, and in the case of gaseous substances the differences between these two experimenters may amount to as much as 2 per cent. In the current number of the Zeitschrift für physikalische Chemie Julius Thomsen has a critical paper on the causes of these differences, and comes to the conclusion that for gases the explosion with compressed oxygen in a bomb gives quite untrustworthy results. His chief argument is based on the comparison of the values obtained for the heats of combustion of homologous series of hydrocarbons and their halogen derivatives, and it is shown that whereas the method of combustion at ordinary atmospheric pressure gives remarkably constant differences between the consecutive members of such a series, the results obtained by means of the calorimetric bomb lead to differences between consecutive members which are quite irregular. It follows that the values obtained for heats of formation, which lie at the basis of all theoretical speculations in this field, are still more irregular in the case of figures obtained with the bomb, since they are based on the differences between the heats of combustion. The weak point in most physical work on gases is usually on the chemical side, and on account of the extreme practical and theoretical importance of the subject and the great advances made in the last ten years in the methods of preparation of pure gases, there is still room for a re-determination of these constants. In this connection it may be pointed out that the ultimate mode of calibration of gas calorimeters of the Junker type is the combustion of a known quantity of a pure gas the heat of combustion of which is taken as known.

G. N. H.

\section{UNIVERSITY AND EDUCATIONAL INTELLIGENCE.}

OXFord.-The following is the text of the speech delivered by Prof. Love in presenting Prof. E. Ray Lankester for the degree of D.Sc. honoris causa on June $13:-$

Salutat Academia nostra Edwinum Ray Lankester, alumnum suum. Hic ille est, cuius magna apud nos est memoria Anatomiæ Comparativæ cathedram olim tenentis, quod et discipulis ardorem suum miro modo inspirare potuit, et specimina in usum Musæi nostri diligentissime congesta ita novis rationibus collocavit ut Historiæ Naturalis principia luce clariore illustraret: qui hane Acadeniiam ut suos mores emendaret toties hortatus est, quæ ad inauditam perfectionem iamdudum pervenisset si monitori amicissimo in Actis Diurnis contionanti obtemperare voluisset. Hic est cuius ex repertis laudis aliquid ad suam Almam Matrem redundavit, cum inter insignissimos doctores qui hodie de animalium figuris disputant fere princeps sit et in omnibus virorum doctorum societatibus summo in honore habeatur.

Nihil profecto quod ad Anatomiam Comparativam pertinet non in huius viri scientiam cadere videtur. Neque enim huic satis erat edendi curam suscipere cum Acta illa, quæ summæ auctoritatis in hoc genere apud nos sunt, labore per quinque et triginta annos iam continuato, tum luculentissimorum librorum seriem, e quibus plures iam typis impressi in manibus omnium habentur, quod onus 